\title{
Svájc közösségi közlekedése
}

A közlekedési szolgáltatások megrendelése három szintű, ú.m.: a Svájci Szövetségi Állam, a kantonok (tartományok) és az önkormányzatok (települések). Az állam felelős az országos és - utóbbi esetben a kantonokkal közösen - a regionális (helyközi, de nem országos érdekü) hálózati kínálatért. A helyi közlekedéshez a szövetségi államnak gyakorlatilag nincs köze, ezt a kantonok rendelik meg az érintett önkormányzatokkal közösen. Az üzemeltetési és finanszírozási feladatok is e hármas tagolódás mentén történnek. A részletes bemutatás alkalmas lehet a hazai gyakorlattal történő összevetésre, és esetleg egyes elemek átültetésére, illetve a jövőbeni intézkedéseknél a figyelembevételre.

DOI 10.24228/KTSZ.2018.6.1

\section{Dr. Szeri István - Hauenstein Mátyás}

Közlekedéstudományi Intézet Személyközlekedési Igazgatóság

e-mail: szeri.istvan@kti.hu, hauenstein.matyas@kti.hu

\section{A SVÁJCI KÖZÖSSÉGI KÖZLEKE- DÉSI RENDSZER TULAJDONSÁ- GAI}

Svájc nem tagja az Európai Uniónak, ezáltal szabályozási kérdésekben sem köteles minden területen megfelelni az EU-s elvárásoknak. Az alábbiakban először is bemutatjuk a svájci közösségi közlekedési rendszer sarokszámait és alaptulajdonságait, majd a későbbiekben gyakorlatiasabb megközelítésben tárgyaljuk az országon belüli viszonyokat. Svájcban a távolsági közlekedést (gyakorlatilag majdnem kizárólag) a vasút biztosítja. A regionális közlekedésben fontos szerepet töltenek be az autóbuszok is. A svájci közigazgatási rendszer működése és összetettsége egyedülálló. Svájc szövetségi köztársaság, amit 26 kanton alkot. A következő fejezetekben többek között azt is tisztázzuk, hogy mi a szövetségi állam és a kantonok közötti feladat-, forrás- és szerepkörmegosztás.

\subsection{Teljesítményadatok}

Az utolsó teljesen publikus adathozzáférési évben (2014) összesen 2,06 milliárd utas utazott közösségi közlekedéssel. Az utazások háromnegyede közúton (autóbusszal, villamossal, trolibusszal), egynegyede vasúton történt. A 24,8 milliárd utaskilométer 82 százaléka (20 milliárd) a vasúthálózaton jött össze, ennek háromnegyede a távolsági közlekedésben. A regionális helyközi közlekedés részaránya a teljesítményben 36 százalék (vasúton 6,9 milliárd, autóbuszon 1,5 milliárd, villamoson 220 millió utaskm). A helyi közlekedés teljesítménye kb. 2,5 milliárd utaskm (ebből 1,4 milliárd a villamos vagy trolibusz, 1,1 milliárd autóbusz részesedése).

A Svájci Szövetségi Vasutak (SBB) szintjén a következőek jellemzőek 2016-ban: az SBB utasteljesítménye 18960 millió utaskm volt, ebből távolsági 13742 millió utaskm, regionális 5218 millió utaskm (ebből autóbusz 24 mil- 
lió utaskm); utasszámban mérve 458,4 millió fö volt a teljesítmény. A járművek kihasználtsága átlagosan 28,0\% (távolsági: $31,1 \%$, regionális: 22,1\%), 128 főt járművenként. Az átlagos utazási távolság 40,2 km.

A kínálati teljesítmény 151,8 millió járműkm (ebből 68,9 millió jkm távolsági, 82,9 millió jkm regionális, utóbbiból 3,2 millió jkm autóbusz), ami 68,642 férőhely-km-nek felel meg (távolságiban 640, regionálisban 306, átlagban 452 fö/jármü értékekkel). Átlagosan napi közel 9000 vasúti járat indult.

\subsection{Finanszírozás}

A távolsági közlekedés koncesszióját eddig teljes egészében a Svájci Szövetségi Vasutaknak (SBB) ítélték oda. Az SBB a szolgáltatás e részét állami költségtérítés nélkül végzi. A regionális helyközi közlekedést a Szövetségi Állam és a kantonok (tartományok) közösen rendelik meg a szolgáltatóktól (az SBB mellett ezen már nagyon sok egyéb közlekedési cég is osztozik). A koncessziók itt két évig érvényesek, de lehet hosszabbítani (bővebben a 2. fejezetben). A fedezetlen költségeket a Szövetségi Állam és a kantonok adóbevételből térítik, a kantonok pedig az önkormányzatokat is bevonhatják a költségtérítésbe. A helyi közlekedés finanszírozása a kantonok és az érintett önkormányzatok közös feladata, de ebben az egyes kantonok jogszabályai nem egységesek.

A finanszírozásról szóló bekezdés könnyebb megértéséhez érdemes néhány szót ejteni a svájci adórendszerröl: van külön állami (ezt a Szövetségi Állam szedi be), kantoni és önkormányzati adó, tehát a közigazgatás mindhárom szintje külön adóbevétellel rendelkezik ( $a$ kantonok és önkormányzatok ráadásul maguk állapítják meg az adókulcsot).

A Svájci Szövetségi Vasutak (SBB) finanszírozását számszerüsítve is bemutatjuk.

A társaság rendszeres támogatást csak a regionális személyszállításra, valamint a pályainfrastruktúra fenntartásra kap.
A társaság költségeiben a személyszállítás a meghatározó (4660,6 millió CHF), az infrastruktúra ágazat költségei 4281,9 millió CHF, míg az áruszállítás 978,0 millió CHF a bruttó 11450,7 millió CHF (konszolidálás után 8699,5 millió CHF) összköltségből.

Fentiekből következően 0,246 CHF/utaskm (0,229 EUR/utaskm, 1,07466 CHF/EUR, 2016.12.31.) volt a fajlagos előállítási költség, illetve 0,0983 CHF/utas (0,0915 EUR/utas) egységben mérve.

2016-ban a személyszállítás költségéből (4660,6 millió CHF) 669,9 millió CHF (14,3\%) volt az állami vagy a kantonok támogatásából fedezve (azaz 85,7\% volt a saját árbevételből történő fedezet aránya). Ebből a támogatásból 624,4 millió CHF-t a regionális közlekedéshez kapott támogatás (293,3 millió CHF szövetségi kormány, 330,9 millió CHF kantonok részéről).

A személyszállításon belül nem érhető el a további költségbontás távolsági és regionális bontásban, de feltételezve a regionális vasúti közlekedés támogatásának veszteségkiegyenlítő jellegét, legalább $846,3 /(846,3+624,4)=57,6 \%$ utasok által (vagy más piaci bevételből) fedezett költség adódik a regionális közlekedésben. A távolsági közlekedésben közel 100\% (pontosabban legfeljebb 98,6\%) a díjbevételből való fedezettség mértéke.

A személyszállítási bevételek között 712,7 millió CHF egyéb bevétel fedezi még a költségeket, amely jórészt kapcsolódó szolgáltatásokból adódik (pályaudvari szolgáltatások, turisztikai célú pénzváltás, jutalék stb.).

Az összképet azonban árnyalja a vasúti infrastruktúra fenntartására kapott 1825,8 millió CHF támogatás (szinte kizárólag szövetségi forrásból), amelyből 1241,3 millió CHF $(68,0 \%)$ amortizációpótló támogatás, 287,6 millió CHF beruházási támogatás, 296,9 millió CHF pályaműködtetési támogatás, amely támogatások szerződéses alapját a szolgáltatás szintü szerződés (SLA) adja. Ebben az összegben benne van a Zürichi Közlekedési Szövetségnek (ZVV) továbbadott 52,0 millió $\mathrm{CHF}$. 
Az infrastruktúra fenntartására kapott támogatás nélkül a személyszállítás pénzügyi eredményessége a fentebb kimutatottnál jóval alacsonyabb lenne.

A társaság 2016. évi pénzügyi folyamatait erősen befolyásolta, hogy 2016. június 1-jén átvette az $57 \mathrm{~km}$ hosszú Gotthárd vasúti bázisalagutat (egy nappal az alagút elkészülte után) az AlpTransit Gotthard AG-töl. Emiatt a társaság hitelállománya a korábbi évek évi $k b .1$ milliárd CHF növekedése helyett 4654,6 millió CHF értékben nőtt, ebből 3754,5 millió CHF hitel a bázisalagúthoz tartozik, további 5990,6 millió CHF vissza nem térítendo” támogatást jelentett a bázisalagút, mint eszköz átadása.

\subsection{Infrastruktúra}

Az SBB vasúti infrastruktúrájának üzemeltetésére és karbantartására a Szövetségi Állam az SBB-vel köt többéves megállapodást (pl. a 2013 és 2016 közötti időszakra). A regionális vasúttársaságok esetében a Szövetségi Állam és a kantonok osztoznak a finanszírozásban. A helyi közlekedés infrastruktúra okozta költségeinek fedezete (pl. villamos és trolibusz felsővezeték karbantartása) a kantonok és az önkormányzatok közös feladata.

\begin{tabular}{|c|c|c|c|}
\hline \multicolumn{4}{|l|}{ SBB által tulajdonolt gördülőállomány (Egység=Darabszám) } \\
\hline & 2014 & 2015 & 2016 \\
\hline Villamos motorvonatok & 492 & 504 & 522 \\
\hline Távolsági motorvonatok & 98 & 99 & 101 \\
\hline Regionális (elővárosi) motorvonatok & 394 & 405 & 421 \\
\hline Vontatójárművek & 141 & 134 & 121 \\
\hline Fővonali mozdonyok & 689 & 688 & 677 \\
\hline Személyszállításra használt & 335 & 335 & 335 \\
\hline Áruszállításra használt & 354 & 353 & 342 \\
\hline Tolatómozdonyok & 244 & 239 & 226 \\
\hline Személyszállításra használt & 54 & 54 & 51 \\
\hline Áruszállításra használt & 92 & 92 & 86 \\
\hline Infrastruktúraüzemeltetés & 98 & 93 & 89 \\
\hline Kétéltű tolatójármüvek & 266 & 262 & 257 \\
\hline Személyszállításra használt & 29 & 29 & 24 \\
\hline Áruszállításra használt & 45 & 41 & 41 \\
\hline Infrastruktúraüzemeltetés & 192 & 192 & 192 \\
\hline Személykocsik & 2379 & 2359 & 2292 \\
\hline Első- és másodosztályú személyszállító kocsik & 1937 & 1923 & 1872 \\
\hline Vezérlőkocsik & 418 & 415 & 411 \\
\hline Poggyászkocsik & 24 & 21 & 9 \\
\hline Teherkocsik & 6816 & 6458 & 5937 \\
\hline Kéttengelyes teherkocsik & 3021 & 2897 & 2677 \\
\hline Négytengelyes teherkocsik & 3795 & 3561 & 3260 \\
\hline Önjáró infrastruktúra fenntartó járművek & 155 & 164 & 155 \\
\hline Infrastruktúra, üzemeltetés, pályafenntartási vontatott kocsik & 1688 & 1745 & 1728 \\
\hline
\end{tabular}




\section{1. ábra: A Svájci Szövetségi Vasutak (SBB) gördülöállományának} életkor szerinti megoszlása (2017)

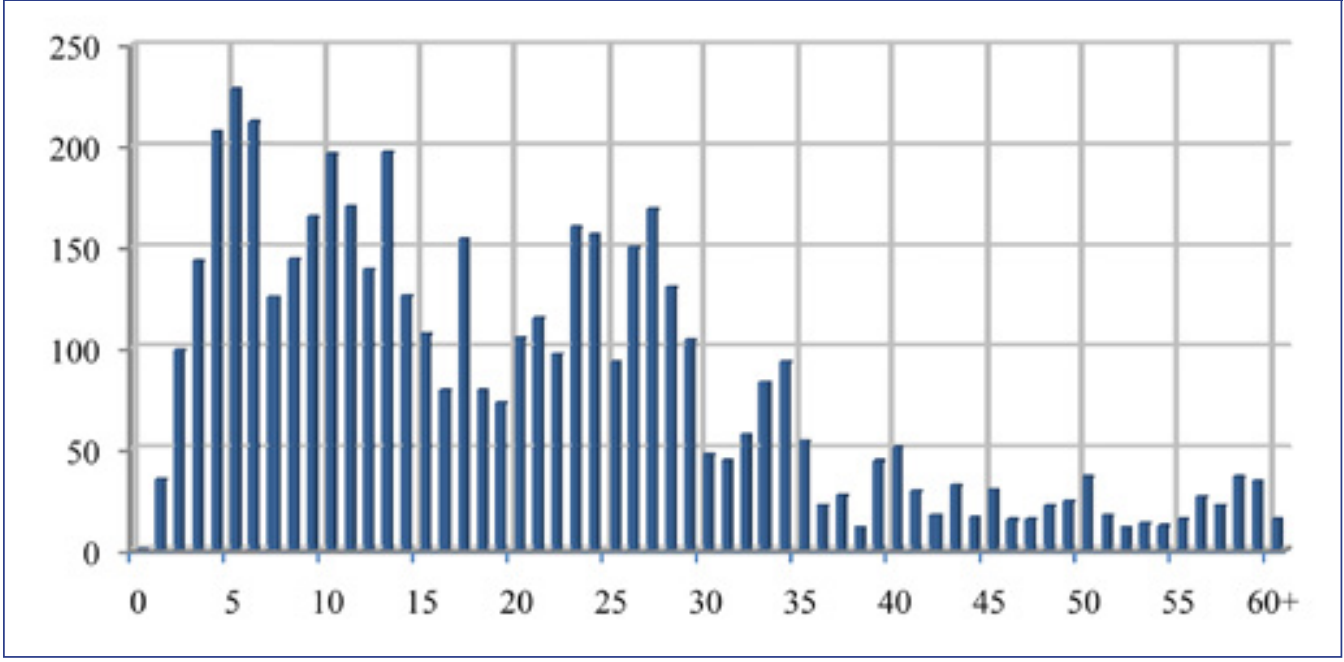

\subsubsection{Vasúti infrastruktúra}

A Svájci Államvasutak (SBB) által tulajdonolt gördülöállomány összesen 11915 darab vasúti jármüvet tett ki 2016-ban, amelyhez az 1. táblázatban nevesített egységek tartoztak.

A gördülöállomány jelentős hányadát a teherkocsik jelentették, összesen 5937 vasúti jármü tartozott ehhez a kategóriához, amelyből 2677 kéttengelyes teherkocsi, míg 3260 négytengelyes teherkocsi. A második legnagyobb számban a személykocsik jelennek meg a teljes gördülöállományon belül. A személykocsik többsége (1872 darab) első- és másodosztályú személykocsi, ugyanakkor ehhez a kategóriához sorolandók a vezérlőkocsik (411 darab), valamint a poggyászkocsik is (9 darab).

A gördülöállományon belül még fontos megemlíteni a villamos motorvonatok, a fóvonali mozdonyok, valamint a tolatómozdonyok számát is. A villamos motorvonatok száma 2016-ban 522 darabot tett ki, amelyek közül 101 a távolsági közlekedésben, míg 421 darab a regionális (elővárosi) közlekedésben vett részt. A fóvonali mozdonyok száma némileg csökkent az elöző évekhez képest, így 2016-ban összesen 677 darab. A fövonali mozdonyok közül 335 darabot személyszállításra, míg 342 vasúti járművet áruszállításra használtak.
Az infrastruktúra, üzemeltetés, pályafenntartási vontatott kocsik száma jelentös még a gördülőállomány nagyságát tekintve. Az ehhez a kategóriához tartozó vasúti jármüvek száma 2016-ban 1728 darab.

Az áruszállításban részt vevő fővonali és tolatómozdonyok száma összesen 428 darab, amelyek közül a fövonali mozdonyok aránya volt a jelentősebb (342 darab).

Amennyiben kizárólag a személyszállítási gördülőállományt kívánjuk meghatározni, akkor arról beszélhetünk, hogy ez 2016-ban összesen 3224 darab vasúti jármü. A számba beletartoznak a villamos motorvonatok, a személyszállításra használt fövonali és tolatómozdonyok, illetve kétéltű tolatójárművek, valamint a teljes személykocsi állomány. Mindez azt jelenti, hogy a teljes gördülöállomány mintegy 27 százaléka lát el személyszállítási feladatokat.

A vasúti gördülőállomány átlagéletkora a 2017. évi állapot szerint 19,8 év.

Amennyiben a gördülőállomány életkor szerinti megoszlását vizsgáljuk, árnyaltabb képet kaphatunk a forgalomban lévő eszközállományról. Az ábrából jól kivehető, hogy a gördülőállomány életkor szerinti megoszlása 


2. táblázat: Közszolgáltatást végző autóbusz-állomány (2016)
\begin{tabular}{|l|c|c|c|}
\multicolumn{5}{|c|}{ Közszolgáltatást végzỏ autóbusz-állomány Svájcban, 2016-ban } \\
\hline Szolgáltató & Darabszám & Csuklós autóbuszok aránya & Átlagéletkor \\
\hline PostAuto & 2242 & $6,50 \%$ & 7,5 év \\
\hline Egyéb szolgáltatók & 2858 & $49,70 \%$ & 6,1 év \\
\hline Összesen & 5100 & $34,40 \%$ & 6,7 év \\
\hline
\end{tabular}

három nagyobb halmazra bontható. Az első halmazba tartoznak azok a vasúti jármüvek, amelyek gyártása óta maximum 15 év telt el. A másik két halmazt a 16-35 éves, illetve a 36 évnél magasabb életkorral rendelkező jármüvek jelentik. A gördülőállományon belül a 15 éves vagy annál fiatalabb vasúti járművek 47 százalékot tesznek ki, míg a második halmaz (16-35 éves) esetében ez az arányszám 41 százalék. Ebből következően a 36 évnél idősebb gördülöállomány adja a minta legkisebb hányadát, mintegy 12 százalékot.

\subsubsection{Autóbuszos infrastruktúra}

A PostAuto Schweiz AG a buszos ágazat legfontosabb és egyetlen olyan szolgáltatója, amely szinte az egész országban képviselteti magát. A többi szolgáltató csak egy-egy régióban aktív. A hozzávetőlegesen $5100 \mathrm{db}$ (2014-es adat) közszolgáltatást végző autóbusz közül (2016-ban) 2242 darabot üzemeltetett a legnagyobb szolgáltató, a PostAuto (2. táblázat). Ezek közül csak $332 \mathrm{db}$ volt csuklós. $\mathrm{Az}$ alacsony szám abból következik, hogy a PostAuto inkább a kifejezetten vidéki térségekben szolgáltat, a nagyobb városok agglomerációin belül csak kevés vonalat üzemeltetnek. A PostAuto flottájának átlagéletkora 2016-ban 7,5 év.

A teljes 5100 db-os állományból 2858 darab autóbuszt több tucat egyéb szolgáltató üzemeltet (a Verband öffentlicher Verkehr számai alapján a közszolgáltatást Svájcban 250-nél is több cég biztosítja, de ebben a számban a vasutak és a nem kizárólag turisztikai célú kötélpályák és hajóvállalatok is benne vannak). Ezek közül elég jelentősek, mint például Genf vagy Zürich közlekedési vállalatai - 200-nál is magasabb darabszámú autóbuszflottákkal -, de akad bőven olyan operátor is, amely tíznél kevesebb busszal végez közszolgáltatást. A 2858 busz átlagéletkorának a becsléséhez hat szolgáltató összesen 726 db autóbuszáról álltak rendelkezésre számok, az átlagéletkor ezeknél 6,13 év. A csuklós buszok itt már sokkal nagyobb darabszámmal fordulnak elő, sőt a vizsgált 15 szolgáltató összesen 1160 db autóbuszának majdnem fele, 577 db csuklós.

A PostAuto 2242 db autóbuszának a pontos és a többi szolgáltató $2858 \mathrm{db}$ autóbuszának a fentebb említett módon felbecsült adatait öszszegezve ki lehet jelenteni, hogy:

Svájcban hozzávetőlegesen 5100 autóbusz végez közszolgáltatást. Ezeknek megközelítően bő egyharmada csuklós, átlagéletkoruk pedig 6,5-7 év.

A jármüveknek a tulajdonjogáról azt érdemes kiemelni, hogy a PostAuto-nak vannak saját jármüvei és alvállalkozók által üzemeltetett buszok is, sajnos ezek megoszlásáról nem közölnek darabszámokat. Annyi biztos, hogy 2016-ban a saját jármüvek költsége (beszerzés, karbantartás) 94,6 millió svájci frank, míg az alvállalkozós járműveké 121,9 millió CHF. Ebből azt lehet valószínüsíteni, hogy darabszámban is magasabb az alvállalkozók tulajdonát képező járművek aránya a saját jármüvek arányánál. Mindenesetre a PostAuto működésében az alvállalkozók jelentős szerepet játszanak, de vannak ellenpéldák is. Például a Bernben és Bern agglomerációjában szolgáltató Bernmobil (a berni „BKK és BKV” egyben, villamossal és trolival is rendelkezik). Néhány kisebb forgalmú buszviszonylat üzemeltetését az 1980-as és 1990-es években ők 
is alvállalkozásba adták, de az utóbbi években arra a következtetésre jutottak, hogy jobban megéri nekik, ha saját maguk üzemeltetik a jármüveket.

\subsection{Jegyrendszer(ek)}

Svájcban népszerüek a különböző bérletek. 2015. év végén a fél áron történő utazáshoz jogosító Halbtaxabonnement-ből 2,3 millió, az összhálózati bérletből (Generalabonnement) 460 ezer példány volt forgalomban (összehasonlításul: Svájc teljes népessége ekkor kb. 8,3 millió fó). Emellett a különböző regionális közlekedési szövetségek által kiadott bérletekből 1,3 millió megváltott példányt számláltak. 2015-ben megjelent a SwissPass nevü bankkártya formátumú chipkártya, amelyre egyelöre még csak a Halbtax- vagy Generalabonnementet lehet rátölteni, de idővel tervezik a termékpaletta kibővítését (pl. regionális bérletek), hogy egy több bérletfajtával rendelkező utasnak már csak egyetlen kártyát kelljen felmutatnia. Svájc közösségi közlekedése gyakorlatilag egy nemzeti közlekedési szövetség, és ez nem csak a bérletek esetében van így. Az ország két tetszőleges pontja között egyetlen jeggyel utazhatunk, függetlenül attól, hogy az útvonalon hány szolgáltató érintett.

\section{A RENDSZER MÜKÖDÉSE A GYAKORLATBAN}

A következőkben bemutatjuk a megrendelöi intézményrendszer szintjeit, felelőseit, valamint a megrendelések jogi hátterét.

\subsection{A közlekedési szolgáltatás megrendelé- sének folyamata}

A szolgáltatás megrendelése három szintű, ú.m: a Svájci Szövetségi Állam, a kantonok (tartományok) és az önkormányzatok (települések). Az állam felelős az országos és - utóbbi esetben a kantonokkal közösen - a regionális (helyközi, de nem országos érdekü) hálózati kínálatért. A helyi közlekedéshez az államnak nincs köze, ezt a kantonok rendelik meg az érintett önkormányzatokkal közösen.
Jogilag a személyszállítási törvény (Bundesgesetzüber die Personenbeförderung) szabályozza a folyamatokat. Az állam, ill. gyakorlatilag a Bundesamt für Verkehr (BAV) mint felelős minisztérium egy szolgáltatónak legfeljebb 25 évre adhat személyszállítási konceszsziót, miután ezzel kapcsolatban egyeztetett az érintett kantonokkal (tartományokkal).

A koncesszió átruházható, módosítható és hosszabbítható.

A megrendelők (állam és kantonok) az általuk közösen megrendelt regionális személyszállítás fedezetlen költségeit a szolgáltatóknak megtérítik; a megrendelők 50-50\%-os arányban osztoznak a költségtérítésen. A kantonok a saját részük esetében az érintett településeket is bevonhatják a költségtérítésbe.

A megrendelési folyamat kétévenként ismétlődik, az állam és az érintett kantonok tehát kétévenként kötnek szerződést a szolgáltatókkal (ez a szerződés tartalmazza a kínálati paramétereket és elözetes becslések alapján a költségtérítést). Elsősorban a keresletet veszik figyelembe, de hangsúlyt fektetnek egy méltányos alapkiszolgálásra ott is, ahol ezt a kínálat nem feltétlenül indokolja, valamint figyelembe veszik pl. az esélyegyenlöségi és a környezetvédelmi szempontokat.

Pályáztatás: A meglévő hálózat esetében nem kötelező, de meg van rá a lehetőség. A megrendelők egy közös tervezetet készítenek a pályáztatni kívánt regionális közlekedési szolgáltatásokról. Ezért elsősorban a kantonok felelnek, az államnak (BAV-nak) inkább koordinációs szerepe van abban az esetben, ha több kanton is érintett. Pályáztatni közúti és vasúti szolgáltatásokat is lehet. Gyakorlatban közúton erre egyre gyakrabban kerül sor.

A vasúti alágazatban viszont annak sajátosságai miatt az eddigi egyetlen ilyen kezdeményezés nem hozta meg a várt eredményt.

A megrendelők a pályáztatási eljárást és a koncesszió megadásának eljárását koordinálják. Pályáztatásra tehát elsősorban akkor kerülhet sor, ha lejár egy szolgáltató koncessziója. 
A közúti alágazatban akkor kötelező a pályáztatás, ha egy új koncesszió kiadása szükséges, azaz új vonal üzemeltetésének esetében. Meglévő koncesszió alapján akkor kerül sor pályáztatásra, ha az érintett kanton(ok) pályáztatási tervezete ezt tartalmazza. Amennyiben nem, akkor a koncesszió pályáztatás nélkül hosszabbításra kerül.

A távolsági közlekedés (amit hazánkban országos szegmensnek hívunk) Svájcban szinte kizárólag a vasúti hálózaton történik. Egy-két olyan távolsági autóbuszvonal létezik, amely turisztikai mellett hivatásforgalmi igényeket is kiszolgál, de azok jogilag a regionális hálózatok részét képezik. A Svájci Szövetségi Vasutak (SBB) személyközlekedési ágazata egyedüli társaságként rendelkezik egy távolsági közlekedési koncesszióval, amelyben megfogalmazták a minimális kínálatot, amit az országos hálózaton biztosítania kell. Az állam a távolsági közlekedést ezen felül azonban nem rendeli meg és költségtérítés sincs. Az SBB az országos vonatokat tehát gyakorlatilag saját üzleti kockázatra üzemelteti, vagyis a jól kihasznált viszonylatok üzemeltetéséből keletkező nyereséget kell a kevésbé kihasznált viszonylatokon keletkező veszteség kompenzációjára fordítania.

A vasúti infrastruktúrát az állami tulajdonú (Svájci Szövetségi Állam vagy kantonok tulajdonában lévő) vasúttársaságok pályavasúti ágazata üzemelteti és tartja karban. A legfontosabb infrastruktúra-kezelők (az SBB mellett a BLS és az SOB) egy független pályakapacitáselosztó nonprofit céget (TrasseSchweiz AG, röviden trasse.ch) alapítottak a hazai VPE-hez hasonlóan. Pályahasználati díjat természetesen fizetnek a hálózatot használó személyvagy teherszállító vasúttársaságok, de ez nem a trasse.ch-n keresztül történik, azok csak az elosztással foglalkoznak.

Svájcban szinte minden agglomerációban van zónás rendszerü tarifaközösség. Emellett gyakorlatilag az egész ország egy nagy tarifaközösség, mert évtizedek óta egységes a jegyrendszer, így az utasok egyetlen menetjeggyel eljuthatnak A-ból B-be közösségi közlekedéssel úgy, hogy közben mindkét alágazatot és több szolgáltatót is igénybe vesznek. A "Direkter Verkehr", azaz közvetlen közlekedésnek nevezett rendszerre nagyon büszke a (szinte) összes helyi és helyközi szolgáltatót tömörítő VöV (Verband öffentlicher Verkehr), amely egyébként az országos bérlet (Generalabonnement) bevételeinek igazságos elosztásáért is felelős.

\subsection{Az alapellátás jogi szabályozása}

Jogilag a személyszállítási törvény Bundesgesetzüber die Personenbeförderung (PBG) szabályozza a folyamatokat. Az állam, ill. gyakorlatilag a Bundesamt für Verkehr (BAV) mint felelős minisztérium egy szolgáltatónak legfeljebb 25 évre adhat személyszállítási koncessziót, miután ezzel kapcsolatban egyeztetett az érintett kantonokkal (tartományokkal).

A Svájci Államszövetség személyszállításról szóló törvényében (PBG) mindösszesen az alábbi rövid megfogalmazás szerepel az alapellátásról:

\section{3. törvénycikk a feltárási funkcióról}

1. bekezdés: A rendszeres és kereskedelmi alapon történő személyszállitásnak akkor van feltárási funkciója, ha az egész évben lakott településre biztosít eljutást.

2. bekezdés: A Szövetségi Tanács (= kormány) határozza meg, milyen feltételek mellett minösül egy lakott terület az 1 . bekezdés szerinti településnek; különösképpen meghatározza az ehhez szükséges minimális lakosságszámot.

31a. törvénycikk a kínálatról és a megrendelési eljárásról

3. bekezdés: A kinálat meghatározásánál és a fedezetlen költségek kompenzálásánál elsősorban a kereslet a mérvadó. Továbbá figyelni kell:

a. egy megfelelő alapellátás biztosítására;

Ezt pontosítja a svájci közlekedési szaktárca, az Eidgenössisches Departement für Verkehr, Umwelt und Kommunikation (UVEK, magyarul Közlekedésért, Környezetért és Kommunikációért felelős Minisztérium) alá tartozó Bundesamt für Verkehr (BAV) Richtlinie minimale Wirtschaftlichkeit im regionalen 
Personenverkehr (RPV) címü irányelve. Ez a regionális közösségi közlekedés minimális költségfedezési arányáról szól.

\section{3. cikk a kínálat kategorizálásáról}

1. bekezdés: A minimális költségfedezési arány meghatározásához az összes közösen megrendelt [tehát az Államszövetség és a kantonok által közösen megrendelt] vonalak két kategóriába sorolandók.

a. Alapellátás legfeljebb óránként közlekedö autóbusszal, telebusszal vagy drótkötélpályával

- Egy több mint 100 fó által lakott, a PBG 3. törvénycikkének megfelelö településre az egyetlen vagy legfontosabb eljutást biztositó autóbuszvonal, legfeljebb óránkénti járatkövetéssel (napi max. 18 járatpár hétfötöl péntekig);

- Egy több mint 100 fó által lakott, a PBG 3. törvénycikkének megfelelö településre az egyetlen vagy legfontosabb eljutást biztositó telebusz-szolgáltatás.

- Egy több mint 100 fó által lakott, a PBG 3. törvénycikkének megfelelö településre az egyetlen vagy legfontosabb eljutást biztositó drótkötélpálya.

b. További buszvonalak és további telebuszszolgáltatások (beleértve az éjszakai közlekedést is), további drótkötélpályák, továbbá vasútvonalak és hajójáratok - ezeket már nem részletezzük, mivel nem a kötelezö alapellátás része.

2. bekezdés: A minimális gazdaságosság feltételei kategóriánként külön kerülnek megállapításra.

Az alapellátást biztosító vonalaknál a megtérülés arányának el kell érnie a $10 \%$-ot, a további vonalak esetében a $20 \%$-ot. Ha egy vonal megtérülése ennél rosszabb, az Államszövetség nem támogatja a megrendelését, de ettől függetlenül a kantonok (tartományok) vagy a községek még megrendelhetik a szolgáltatást, állami támogatás nélkül.

\section{3. ÖSSZEFOGLALÓ}

A svájci települések közösségi közlekedését az állam az alábbi feltételek mellett támogatja:

- a település legyen egész évben lakott,

- legyen több mint 100 fős népessége,
- az alapellátását biztosító szolgáltatás (legyen szó akár autóbuszról, telebuszról vagy drótkötélpályáról stb.) költségének legalább 10 százaléka térüljön meg.

\subsection{Tarifa, kedvezmények és intermodalitással kapcsolatos kérdések}

\section{- Tarifamegállapítás hatásköre, tarifa mér- téke}

A viteldíjat a Direkter Verkehr (ch-direct) nevü iroda állapítja meg, amely a svájci közösségi közlekedésben résztvevő szolgáltatók egyesüléséhez (Verband öffentlicher Verkehr - VöV) tartozik. Az állam részéről a Preisüberwacher (árfelügyelö) felügyeli a díjszabást, tehát gyakorlatilag ő hagyja jóvá a tarifaemeléseket. Az alaptarifa 2. osztályú jegy esetében jelenleg díjszabási kilométerenként 0,4451 svájci frank (CHF). A minimális viteldíj 3 CHF.

\section{- Utazási kedvezmények mértéke, megálla- pításának hatásköre, finanszírozása}

Svájc: a 6 éven aluliak ingyen utaznak egy olyan ítélöképes személy kíséretében, akire rá lehet bízni a gyerekek felügyeletét (legfeljebb 4 gyerek esetében a 12., legfeljebb 8 gyerek esetében a 16. életévét betöltött személy). Ha az egy fö kísérőszemélyre jutó 6 éven aluliak száma 8-nál nagyobb, a további gyerekek esetében félárú menetjegyet kell váltani.

6 és 16 év közötti gyerekek/ifjak 50\% kedvezményben részesülnek. Amennyiben a 6 és 16 év közöttiek a szüleikkel vagy nagyszüleikkel együtt utaznak, családi kedvezmény igényelhető. Mindkét esetben egy személyre szóló kártyát (Junior-Karte vagy Enkel-Karte) kell váltani, amely biztosítja a 100\%-os árkedvezményt. Nyugdíjasok a teljes viteldíjat fizetik, de egyes szolgáltatók kedvezményt biztosíthatnak, amely nem haladja meg a $33 \%$-ot.

Fogyatékos személyeknek is teljes árú jegyet kötelező váltani, de ha kísérőszemélyre vagy vakvezető kutyára van szükségük, ez utóbbiak ingyen utazhatnak (akár kísérőszemély és vakvezetö kutya együtt is). 
A finanszírozásról: A megrendelők (állam és kantonok) az általuk közösen megrendelt regionális személyszállítás fedezetlen költségeit a szolgáltatóknak megtérítik; a megrendelők 50-50\%-os arányban osztoznak a költségtérítésen. A kantonok a saját részük esetében az érintett településeket is bevonhatják a költségtérítésbe.

\section{- A jegyrendszer egységességére vonatkozó gyakorlatok}

Svájcban - mint említésre került - szinte minden agglomerációban van zónás rendszerü tarifaközösség. Emellett gyakorlatilag az egész ország egy nagy tarifaközösség, mert évtizedek óta egységes a jegyrendszer, így az utasok egyetlen menetjeggyel eljuthatnak A-ból B-be közösségi közlekedéssel úgy, hogy közben mindkét alágazatot és több szolgáltatót vesznek igénybe. A "Direkter Verkehr", azaz közvetlen közlekedésnek nevezett rendszerre nagyon büszke a (szinte) összes helyi és helyközi szolgáltatót tömörítő VöV (Verband öffentlicher Verkehr), amely egyébként az országos bérlet (Generalabonnement) bevételeinek igazságos elosztásáért is felelős. Nemrég bevezetésre került a SwissPass, egy olyan kártya, amelyre feltölthetők a kedvezmények (egyelöre csak a helyi bérletek és a Generalabonnement).

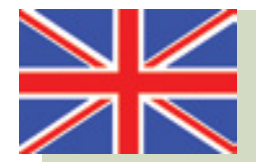

\section{Public Transport in Switzerland}

Switzerland's transport services are ordered on three separate levels: by the Swiss Federal State, the cantons (provinces) and the municipalities (tow ns and villages). The state is responsible for the supply of national and regional (interurban but not national) network services in the country, in the latter case together with the cantons. The federal state has virtually no responsibility for local transport - this is organised by the cantons together with the local municipalities concerned. Operational and financing tasks are also carried out along this triple segmentation. The detailed presentation may be suitable for comparing this system with the domestic practice and possibly for the transposition of some elements or for taking into account future measures.

\section{- Vasút-busz összehangolásra vonatkozó gyakorlatok}

Svájcban a távolsági közlekedést (gyakorlatilag majdnem kizárólag) a vasút biztosítja. A regionális közlekedésben fontos szerepet játszanak az autóbuszok is. A két alágazat az utas felé nem két külön alágazatként jelenik meg, hanem egy egységes rendszerként, nem csak a jegyrendszert illetően. Az alágazatok és szolgáltatók együttműködése teljesen természetes dolog, pl. késések kommunikálása az átszállási pontokon.

\section{FELHASZNÁLT IRODALOM}

[1] Financial Report 2016 URL: https:// company.sbb.ch/en/media/publications/ financial-report.html

[2] SBB Facts and Figures URL: https:// reporting.sbb.ch/

[3] https://www.admin.ch/opc/de/classifiedcompilation/20061345/index.html\#a3

[4] https://www.voev.ch/de/

[5] https://www.voev.ch/de/Service/ Publikationen/VoeV-Schriften/Faktenund-Argumente-zum-oeV-Schweiz

[6] http://www.ch-direct.org/de/ch-direct

[7] http://www.trasse.ch/10151/10028/?oid=10 083\&lang=en

[8] https://company.sbb.ch/de/home.html

[9] https://www.postauto.ch/de/ueber-postauto 